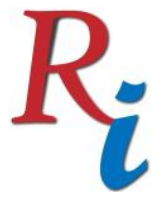

Asia Proceedings of Social Sciences

(APSS)

www.readersinsight.net/APSS

\title{
STUDENT ENGAGEMENT IN HAIR STYLE LEARNING
}

\author{
Aniesa Puspa Arum* \\ Departement of Education Technology \\ Universitas Negeri Jakarta \\ Indonesia \\ Nurdin Ibrahim \\ Departement of Education Technology \\ Universitas Negeri Jakarta \\ Indonesia \\ Etin Solihatin \\ Departement of Education Technology \\ Universitas Negeri Jakarta \\ Indonesai

\section{Jhoni Lagun Siang} \\ Departement of Education Mathemathic \\ Bumi Hijrah University \\ Indonesia
}

*Corrosponding author's Email: aniesa.puspa@gmail.com 


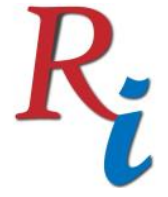

\section{Asia Proceedings of Social Sciences}

(APSS)

www.readersinsight.net/APSS

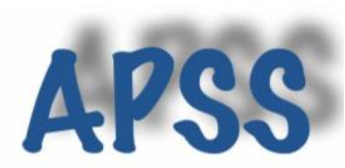

\section{Rese a r ch H igh I ights}

The purpose of this study was to determine the student engagement in hair style learning. The sample of this research was 90 students taking hair style learning in the Cosmetology Study Program, Faculty of Engineering, Universitas Negeri Jakarta. The type of research used is quantitative descriptive. Data collection was carried out by distributing learning engagement questionnaires to students consisting of 4 indicators including: skills, emotional, participation and performance, using a Likert scale. After the data is collected it is processed with SPSS. The results of the study revealed that as many as $47(52.2 \%)$ students had high engagement in hair style learning and 43 (47.8\%) students had low engagement in hair style learning.

Keyword: Student Engagement, Learning, Hair Style Courses

\section{Research Objectives}

The success of a student in understanding lecture material and achieving graduation is largely determined by the activeness of the learning process. This student learning process can be maximized by involving the affection, cognition, and social interaction of students in their learning process, can be known as student engagement.

Student Engagement is also marked by the intrinsic motivation of students to undergo the learning process. Intrinsic motivation to undergo the learning process referred to here is that students undergo the learning process as a personal need not because of pressure from outside themselves. Their goal is to meet personal needs not just to obey others' commands without understanding the benefits. Motivation models and motivational theories focus on factors that influence student engagement in activities related to achievement.

Aside from being a good predictor of students, this student engagement can also act as a predictor of effective teaching, this student engagement can provide feedback to educators about how effective their teaching is, including how much motivation students have in following their lessons. Educators who understand student engagement can evaluate and modify the learning model when delivering lessons so that they can maximize the learning process in hair style courses. 


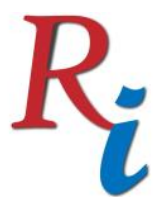

\section{Asia Proceedings of Social Sciences}

(APSS)

www.readersinsight.net/APSS

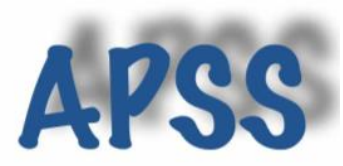

Hair styling is an act of embellishing hair with all the stages that can be given to someone through the arrangement of his hair in accordance with a design that aims to change one's appearance. With the practice of hair styling, one can develop creative ideas and can apply beautiful hair styling in accordance with the shape of the face. Hair styling is the last step in a series of actions, in the process of handling hair that aims to give the impression of beauty, neatness and harmony for a person, according to aesthetic values applicable in a certain period (Harahap, 2008: 85). Hair styling is an important thing that can be done alone or with the help of stylish hair with a variety of techniques and designs that are simple and attractive (Kusumawardhani, 2010: 7).

Hair style courses are compulsory follow-up courses taken by students after graduating from previous courses, namely: drawing mode, haircuts, hair care and presets. Where all the courses are theoretical and practical and require deep thinking, sharpening creativity and pouring ideas in the form of designs or patterns of an object that you want to display. Therefore, spatial intelligence is needed.

According to Handelsman et. al. (2005) Student engagement is an initiation of students' actions, efforts and persistence in their school work, as well as their overall emotional state during learning activities. Reeve provides another definition of student engagement, namely, intensity of behavior, emotional quality, and personal effort of active student involvement in learning activities Reeve, J. (2005). Handelsman et. al. (2005) explained that from various definitions available, student engagement as a whole can be seen from four factors. The four factors are skill engagement, emotional engagement, participation / interaction engagement, and performance engagement.

Various studies explain that there are several factors that influence the level of student engagement. Because the sample to be used in this study is students, it is important to know what factors influence student engagement. Transgurd et al., Explained that student engagement can be influenced by five factors, namely (1) the level of academic challenges, (2) the relationship between students and faculty, (3) active and collaborative learning processes, (4) enrichment of educational experience, and (5) a supportive campus environment (Lanasa, Cabrera, \& Transgurd, 2009).

There is a difference in students who have friends with high academic quality and students who have friends with low academic quality. Students who study on campus with high-quality students, will make their behavior and academic performance higher than if they attended the 


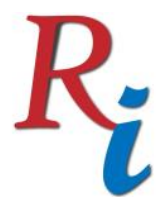

\section{Asia Proceedings of Social Sciences}

(APSS)

www.readersinsight.net/APSS

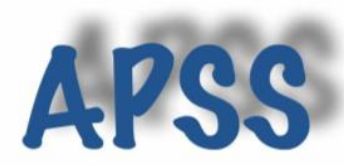

campus with low-quality students. The explanation above can be illustrated in the form of a diagram of the influence of institutional structure on student engagement by Porter as below:

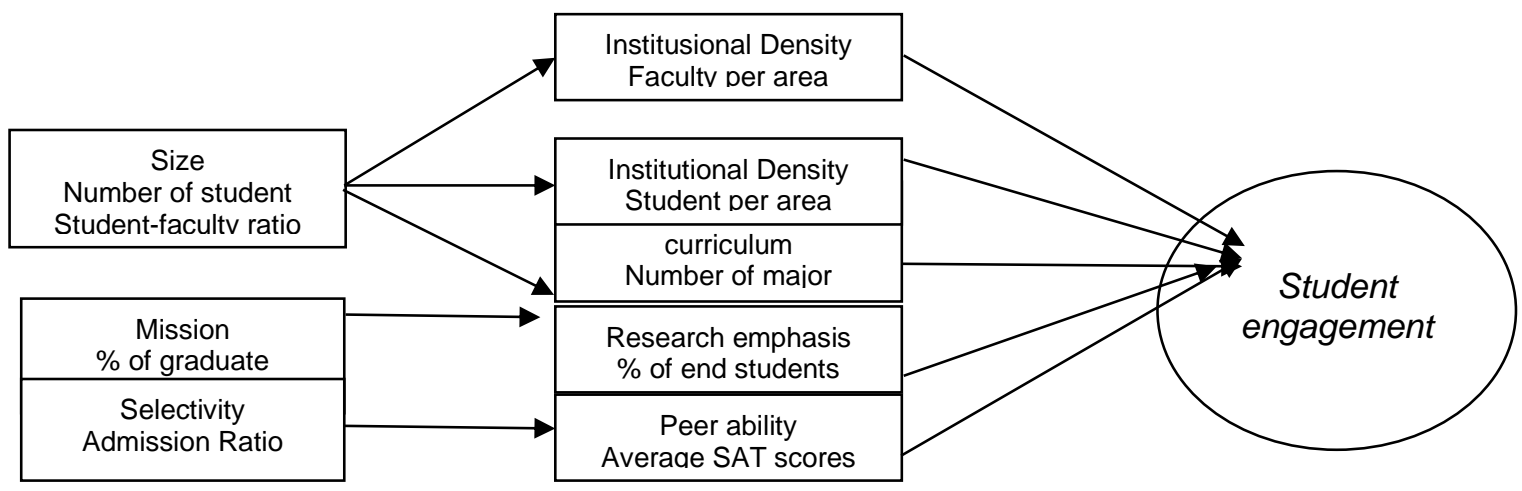

Fig..1. How Institutional Structures Affect Student Engagement by Porter. Institutional

Structures and Student Engagement. 2006.

From the explanation of the theory above, it can be concluded that engagement skills, emotional engagement, participation / interaction engagement, and performance engagement can show how far the level of student engagement a student has, seen from the change in attitude in the form of interest and enthusiasm in learning. It is important for educational institutions to know the picture of student engagement in students, because the role of student engagement can show the extent of the success of the learning process that students run.

\section{Methodology}

The research method used was descriptive survey method. According to Sevila the descriptive research method is a method designed to gather information about real or actual and ongoing conditions Consuelo B. Sevila, et. al. (1993). In this study the instrument used was a list of statements (questionnaire) or questionnaire. According to Abdulwahab, the questionnaire was used in indirect communication techniques, meaning that the respondent indirectly answered written questions sent through certain media (Wisnijati Basuki Abdulwahab, 2002). In the questionnaire answers were provided so that the respondent only had to mark the selected answers (Suharsimi Arikunto, 1992). To measure the variable used Likert scale.

Data collection in this study was carried out by distributing questionnaires to 90 respondents totaling 23 statements with indicators: (1) Skill Engagement, (2) Emotional Engagement, (3) Participation / Interaction Engagement, and (4) Performance Engagement, in order to determine the level of student engagement in hair style courses. The data analysis technique 


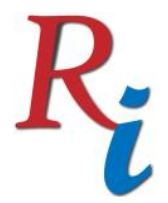

\section{Asia Proceedings of Social Sciences \\ (APSS) \\ www.readersinsight.net/APSS}

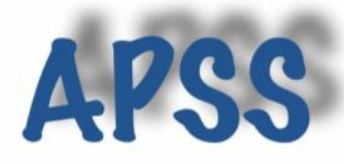

used in this study is a quantitative descriptive analysis technique using a frequency table. The results of the analysis are expressed in terms of a percentage and divided into two categories, namely high student engagement for SS and S answers and low student engagement for STS and TS answers. The results are processed using primary data such as maximum value, minimum value and average value in order to obtain descriptive respondents from variable data. The data distribution is displayed in tables and figures. Raw data is calculated based on the Likert scale formula with a score of 1-4. Then the research data that has been collected will be processed using SPSS.

\section{Results}

In this section the results of the study will be explained based on the results of the calculation of the indicators which are then distributed to the frequency which is then analyzed according to the results of the sum of the indicators.

Table.1. Average Total Student Engagement

\begin{tabular}{llllll}
\hline & & Frequency & Percent & Valid Percent & Cumulative Percent \\
\hline \multirow{3}{*}{ Valid } & Low & 43 & 47,8 & 47,8 & 47,8 \\
& High & 47 & 52,2 & 52,2 & 100,0 \\
& Total & 90 & 100,0 & 100,0 & \\
\hline
\end{tabular}

From the results of the statistical average measurement based on indicators it can be seen that from 90 respondents there were 47 or $52.2 \%$ of students who had high engagement in hair style courses and 43 or $47.8 \%$ of students who had low engagement in hair style courses. This can be caused by each sub-indicator having a high yield that affects each indicator. It can be seen after the accumulation of the results that more respondents have high student engagement in the hair style courses. The results of this study prove that, students have a high engagement in hair styling courses to support appearance, of course supported by good and deep knowledge of scalp and hair.

Based on the results of the study, cosmetology students amounting to 90 people, have a high engagement in the hair style course. It can be seen from the results of research that show that in the frequency distribution table which is then made score categorization, the results indicate that the categorization at high frequency values is greater than the categorization at low value, 


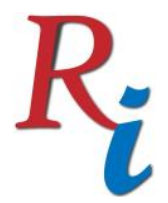

Asia Proceedings of Social Sciences

(APSS)

www.readersinsight.net/APSS

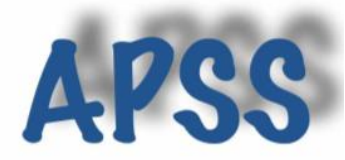

which is 47 compared to 43 people or $52.2 \%$ compared to $47.8 \%$. The following table for the results of categorizing scores can be seen as below:

Table 2. Results of Respondent Engagement in Hair style courses

\begin{tabular}{lll}
\hline Score category & Number of Respondents & Percentage \\
\hline High & 47 Respondents & $52,2 \%$ \\
Low & 43 Respondents & $47,8 \%$ \\
Total & 90 Respondents & $100,0 \%$
\end{tabular}

From the results of the study above shows that student engagement in hair style courses is high, because there are 47(52.2\%) of students have a greater score. It can be concluded that students have high engagement in hair style courses. However, their high engagement was not supported by their skills, as seen from the results of the research on the skills indicator, showing that out of 90 respondents, more respondents had low skills in the hair style course at 47(52.2\%) of respondents. The cause of the low skills of students in the hair style course is the influence of the low calculation results of several sub-indicators that affect the average results of student skills indicators. Besides that, the other cause is the inaccurate learning strategy used. The following summarizes the results of the average calculation of each indicator and the final result of student engagement.

Table.3. Summary of Overall Indicator Calculation Results

\begin{tabular}{|c|c|c|c|c|}
\hline Indicator & High & Percentage & Low & Percentage \\
\hline 1.Skill & 43 respondents & $47,8 \%$ & 47 respondents & $52,2 \%$ \\
\hline 2.Emotional & 51 respondents & $56,7 \%$ & 39 respondents & $43,3 \%$ \\
\hline 3.Participation & 49 respondents & $54,4 \%$ & 41 respondents & $45,6 \%$ \\
\hline 4.Performance & 57 respondents & $63,3 \%$ & 33 respondents & $36,7 \%$ \\
\hline $\begin{array}{l}\text { Student engagement in } \\
\text { Hair style learning }\end{array}$ & 47 respondents & $52,2 \%$ & 43 respondents & $47,8 \%$ \\
\hline
\end{tabular}

The results of the calculation of each indicator show that more respondents were has a high engagement in the hair style courses.

\section{Findings}

Based on the results of previous studies and discussions, it can be concluded that the cosmetology student's engagement in the hair style course is high, seen from the greater number 


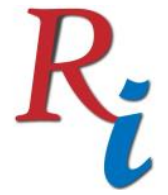

\section{Asia Proceedings of Social Sciences}

(APSS)

www.readersinsight.net/APSS

or percentage of respondents who have high student engagement with low student engagement, which amounted to $52.2 \%$.

\section{Acknowledgement}

Thank God Almighty for all the grace given, so that this research can be completed

\section{References}

Consuelo B. Sevila, et.all. (1993).Pengantar Metode Penelitian, Diterjemahkan oleh Amiludin Tuwu Jakarta: UI-Press, h. 71.

Handelsman et al. (2005). A Measure of College Student Engagement, The Journal of Educational Research, Vol. 98 (3), h. 185.

Harahap, Sartini, dkk. (2008). Tata Kecantikan Rambut Tingkat Trampil. Jakarta: Meutia Cipta Sarana(85).

Kusumawardhani, Reni. (2010). UPDO 24 Simple Hairstyles by Sugimartono. Jakarta: PT Gramedia Pustaka Utama.(7).

Lanasa, Cabrera, \& Transgurd, (2009). The Construct Validity of Student Engagement: A Confirmatory Factor Analysis Approach. Res High Educ, 50, h. 317.

Reeve, J. (2005). How Teacher Can Promote Student's Autonomy During Instruction: Lesson from a Decade of Research. Iowa Educational Research and Evaluation Association,.

Suharsimi Arikunto.1992, Dasar-Dasar Evaluasi Pendidikan.Jakarta: Bumi Aksara, h. 25.

Wisnijati Basuki Abdulwahab.(2002). Statistika Parametrik dan Non Parametrik untuk Penelitian Jakarta: UNJ, h.2.

Author's Biography

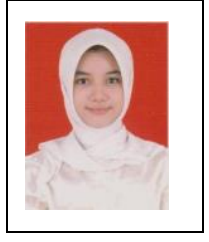

Name: Aniesa Puspa Arum, M. Pd

Place/ Date of Birth: Jakarta, 10 Februari 1988

Citizien: Indonesia Religion: Islam

Copyright (C) 2019 Authors. This is an open access article distributed under the Creative Commons Attribution License, which permits unrestricted use, distribution, and reproduction in any medium, provided the original work is properly cited. 


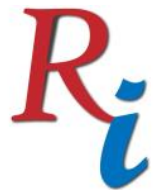

\section{Asia Proceedings of Social Sciences}

(APSS)

www.readersinsight.net/APSS

Status: Married

Address: Jl. Sambisari I Blok A/No. 38. Perum. Duta Kranji. Bintara, Bekasi Barat. 17134

No.Hp: +62-821-2274-9290ＥＥmail /Address: aniesa.puspa@gmail.com

Hobbies: Aerobic, Travelling, Dance

Motto: Do the best in life 